\title{
INFLUENCE OF CHATTER OF VMC ARISING DURING END MILLING OPERATION AND CUTTING CONDITIONS ON QUALITY OF MACHINED SURFACE
}

\author{
A.K.M.N. Amin*, M.A. Rizal, and M. Razman \\ Department of Mechanical Engineering, Faculty of Engineering, IIUM, Gombak, 43100 Kuala Lumpur, \\ Malaysia, e-mail: akamin@iiu.edu.my
}

\begin{abstract}
Machine tool chatter is a dynamic instability of the cutting process. Chatter results in poor part surface finish, damaged cutting tool, and an irritating and unacceptable noise. Extensive research has been undertaken to study the mechanisms of chatter formation. Efforts have been also made to prevent the occurrence of chatter vibration. Even though some progress have been made, fundamental studies on the mechanics of metal cutting are necessary to achieve chatter free operation of CNC machine tools to maintain their smooth operating cycle. The same is also true for Vertical Machining Centres (VMC), which operate at high cutting speeds and are capable of offering high metal removal rates. The present work deals with the effect of work materials, cutting conditions and diameter of end mill cutters on the frequency-amplitude characteristics of chatter and on machined surface roughness. Vibration data were recorded using an experimental rig consisting of KISTLER 3-component dynamometer model 9257B, amplifier, scope meters and a PC. Three different types of vibrations were observed. The first type was a low frequency vibration, associated with the interrupted nature of end mill operation. The second type of vibration was associated with the instability of the chip formation process and the third type was due to chatter. The frequency of the last type remained practically unchanged over a wide range of cutting speed. It was further observed that chip-tool contact processes had considerable effect on the roughness of the machined surface.
\end{abstract}

Key Words: Chatter, Cutting Conditions, Stable Cutting, Surface Roughness.

\section{INTRODUCTION}

Chatter is a type of self-excited vibration, which appears during the metal cutting process. It is undesirable but some times difficult to avoid during machining. Chatter leads to continuous variations of the cutter and the work piece, which leads to low accuracy and surface finish of the machined part. Chatter is also harmful from the point of view of machine and tool life and noise hazards. Research in this area has been focused mainly on the suppression techniques of chatter. Emphasis has been given to chatter monitoring systems with a view to avoiding chatter either by selection of appropriate cutting parameters or through addition of dampers or introduction of forced vibrations of appropriate frequency, amplitude and phase characteristics. There has been also some attempts by a few researchers to determine the primary causes of chatter ${ }^{[2,3]}$. Though there are controversies on the primary causes of chatter formation, it appears more logical to think of chatter as resonant phenomenon, caused due to mutual interaction between the vibrations of machine components, tool, work piece and the fixture system, by their natural frequencies on one hand and the vibrations caused by the instability of the chip formation process, when the frequencies of the two interacting vibrations are either equal or close to each other ${ }^{[2,3]}$. Since the primary cause of chatter is believed to be the instability of the chip formation and that in the development of chatter the natural frequencies of the system components play vital role, the current research is intended to investigate the influence of work material properties, cutting variables, as well as the tool dimensions on generation and the frequency-amplitude characteristics of chatter. The work also aims at determining the pattern of surface roughness produced as a function of both - chatter and cutting conditions. The other parameter investigated, is the fluctuation of the chip thickness as a result of chatter.

\section{EXPERIMENTAL SETUP}

The experiments were performed on Vertical Machining Center model MCFV 1060 with Vickers Acramatic controller model A2100 CNC MC. Multi component KISTLER Dynamometer Type 9257B was used to measure the variation in cutting force. The signals from the dynamometer were amplified by a charge amplifier and recorded by Flurke Scope Meter in waveform. The recorded data in the waveforms were further analyzed by using Flurke View software. A schematic view of the experimental setup is shown in Fig. 1. A sample of the recorded vibration indicating the low and the higher frequencies is shown in Fig. 2. The chips produced under various cutting conditions were investigated to compare the frequencies of fluctuations of chip thickness with the recorded frequency during the cutting. Average surface roughness of the work piece at the face and the radial surfaces was measured using the 
Mitutoyo Surface Roughness Measuring Instrument model: SV 500. The cutting conditions are listed in Table 1. Three types of work materials: aluminum alloy AAN6061, mild steel AISI1020 and stainless steel AISI446 were machined. The hardness of the work materials was measured on Digital Hardness Testing Machine Model ARK-600. The hardness values are given in Table 2. End mill cutters of diameters $20 \mathrm{~mm}$ and $25 \mathrm{~mm}$ were used for machining. The machined surface was examined under the Scanning Electron Microscope (SEM). The photograph of the middle section of the chip was taken after etching using an optical microscope with normal camera.

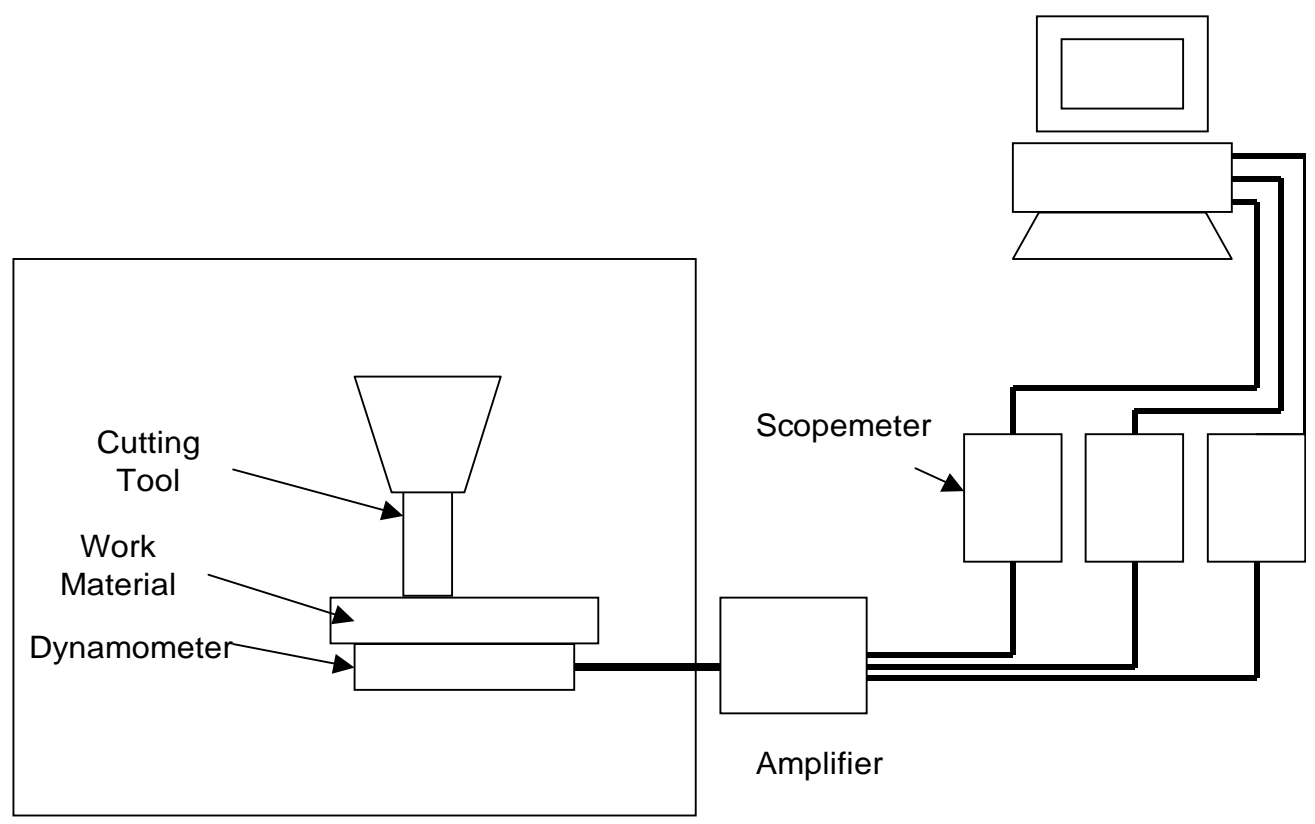

Fig. 1: Experimental Setup

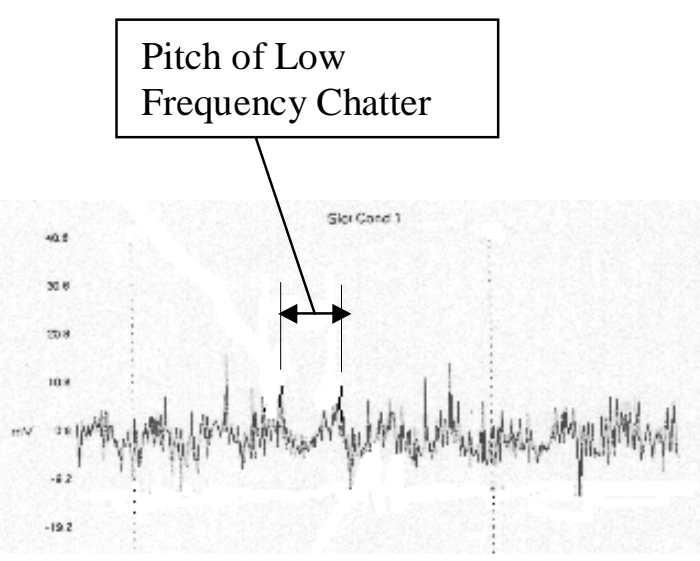

(a)

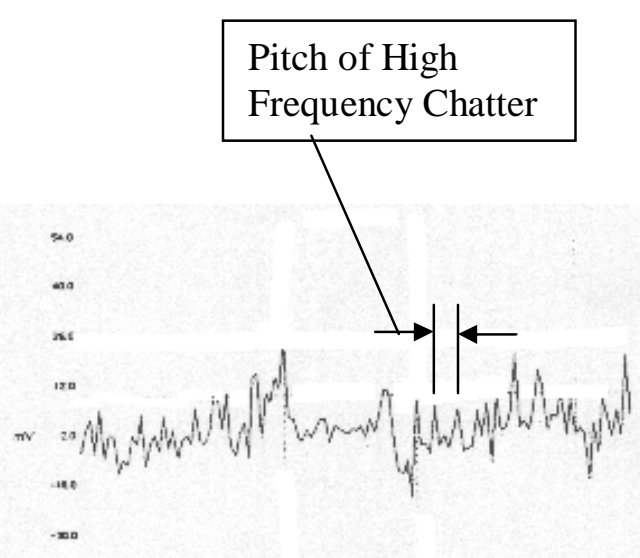

(b)

Fig. 2: Vibration output in wave form at low magnification (a), showing peaks of low frequency chatter and at high magnification (b), showing peaks of high frequency chatter.

Table 1: Values/Ranges of Cutting Parameters

\begin{tabular}{|c|c|c|c|}
\hline \multirow{2}{*}{ Cutting Parameters } & \multicolumn{3}{|c|}{ Workpiece materials } \\
\cline { 2 - 4 } & Al Alloy & Mild Steel & Stainless Steel \\
\hline Cutting Speed, $\mathrm{m} / \mathrm{min}$ & $100-550$ & $25-300$ & -140 \\
\hline Feed, $\mathrm{mm} / \mathrm{tooth}$ & \multicolumn{3}{|c|}{$0.05,0.10$ and 0.20} \\
\hline Depth of Cut, $\mathrm{mm}$ & $1.5,2.0$ and 5.0 \\
\hline
\end{tabular}


Table 2: Work Material Hardness

\begin{tabular}{|c|c|}
\hline Material & Hardness \\
\hline Stainless Steel & $87.1 \mathrm{HRB}$ \\
\hline Mild Steel & $67.5 \mathrm{HRB}$ \\
\hline Aluminum & $55.7 \mathrm{HRB}$ \\
\hline & \\
\hline
\end{tabular}

\section{RESULTS AND DISCUSSION}

Three main types of vibrations were observed during machining of all the three work materials: one with a very low frequency, equal to spindle rpm times the number of cutter tooth, the other one with a medium frequency, mainly responsible for chatter, and the last type was associated with the serration frequency of the chip. Since the highest amplitudes of vibration i.e. chatter phenomenon was associated with the intermediate frequencies, more attention was paid to this type of vibration. The of this frequency range are given in the following sections.

\subsection{Stainless Steel}

Curves of chatter/vibration frequencies and amplitude vs. cutting speed and amplitude and average surface roughness vs. cutting speed were plotted for different combinations of feed and depth of cut. Sample relationships among the above parameters are shown in
Fig. 3 and Fig. 4. The feed and depth of cut values used in these cases were respectively $0.10 \mathrm{~mm} /$ tooth and 2 $\mathrm{mm}$. It is observed from Fig. 3 that the variation in the frequency of vibration is in the range of $395 \mathrm{~Hz}$ to 560 $\mathrm{Hz}$, which is not very high (varies only by $41 \%$ ) and may be considered to be practically constant. The amplitude of vibration on the other hand varies from $10.42 \mathrm{~N}$ to $37.77 \mathrm{~N}$ (by 262\%), which is quite high. This high fluctuation of vibration amplitude may be explained by the appearance of chatter or resonant vibration. Amplitude of chatter varies sharply in the cutting speed range from 35 to $65 \mathrm{~m} / \mathrm{min}$ and then remains almost constant (varies by only 19\%). As it may be observed from Fig 4 that the average surface roughness of the work piece varies from $0.13 \mathrm{~mm}$ to $0.26 \mathrm{~mm}$ for these cutting conditions. The surface roughness values are low in the beginning but increased up to a speed of $95 \mathrm{~m} / \mathrm{min}$ and then dropped. The rise in surface roughness values with cutting speed is related to the increase in amplitude of chatter

In the case of stainless steel the chip shows a serrated nature above $50 \mathrm{~m} / \mathrm{min}$. This phenomenon may be observed from the microphotograph of the middle section of the chip as shown in Fig. 5. Due to intensive tool wear and frequent tool breakages the cutting speed was limited to $140 \mathrm{~m} / \mathrm{min}$. The values of amplitude and surface roughness for two tool holder diameters and other cutting conditions are listed in the Tables 3 and 4 ..

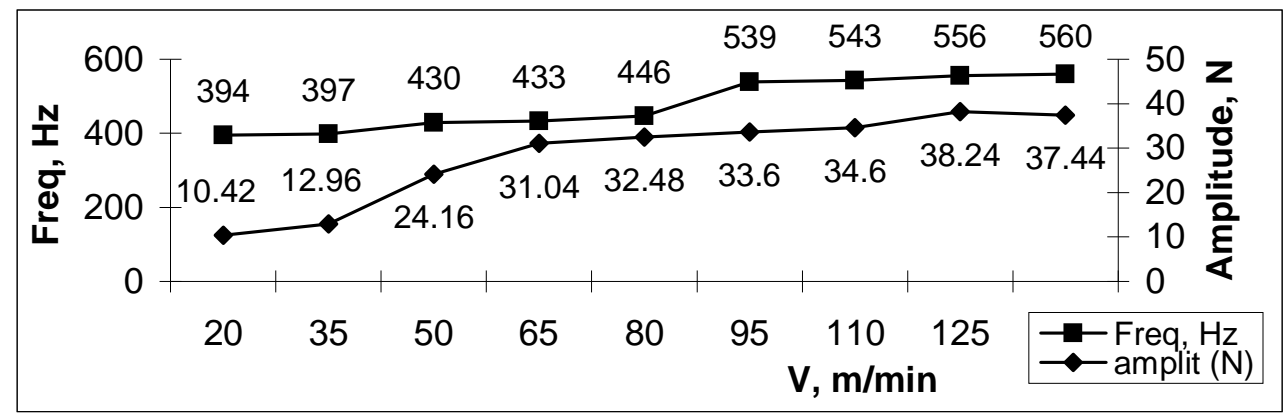

Fig. 3: Variation of frequency and amplitude of chatter with cutting speed. Work Material: Stainless Steel, Feed: 0.10 $\mathrm{mm} /$ tooth, Depth: $2 \mathrm{~mm}$

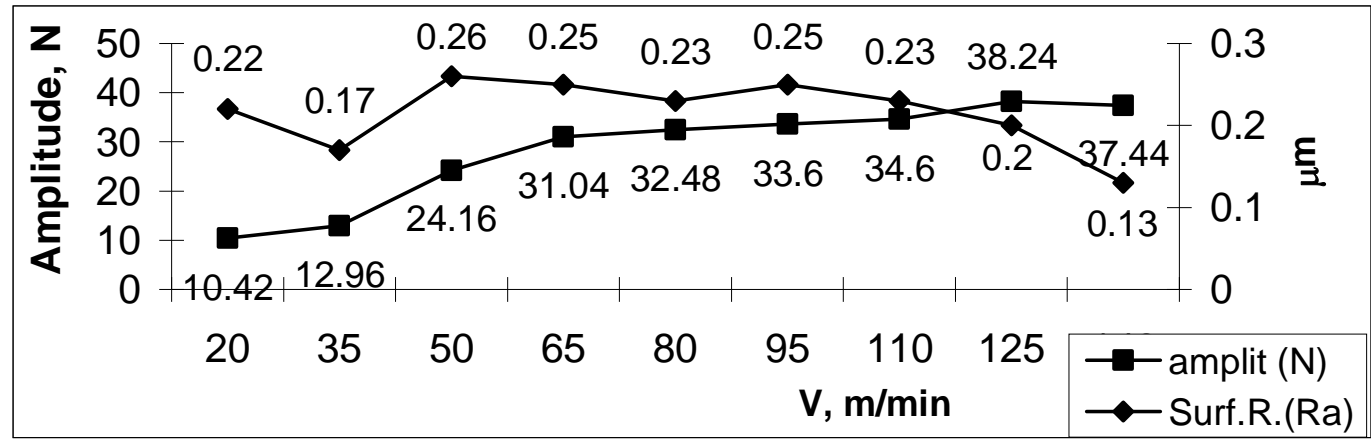

Fig. 4: Dependence of surface roughness on amplitude of chatter and cutting speed. Work Material: Stainless Steel, Feed: $0.10 \mathrm{~mm} /$ tooth, Depth: $2 \mathrm{~mm}$ 

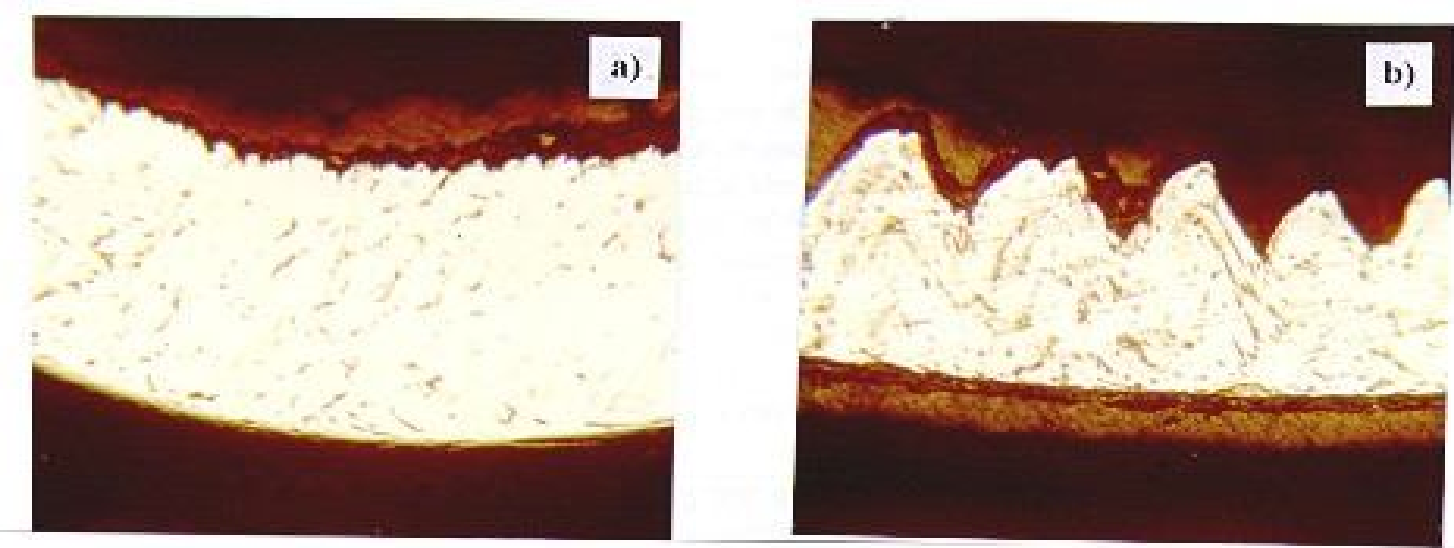

Fig. 5: Photograph of the chip section. Material: Stainless Steel. a) V=45 m/min; b) V=105 m/min

\subsection{Mild Steel}

Curves of chatter/vibration frequencies and amplitude vs. cutting speed and amplitude and average surface roughness vs. cutting speed were plotted for different combinations of feed and depth of cut. Sample relationships among the above parameters are shown in Fig. 6 and Fig. 7. The feed and depth of cut values used in these cases were $0.10 \mathrm{~mm} /$ tooth and $2 \mathrm{~mm}$, respectively. It may be observed from Fig. 6 that the variation in the frequency of vibration was in the range $375 \mathrm{~Hz}$ to $506 \mathrm{~Hz}$ up to a speed of $275 \mathrm{~m} / \mathrm{min}$, which is not very high (varies only by $35 \%$ ) and may be considered to be practically constant. The amplitude of vibration varieds from $10.8 \mathrm{~N}$ to $52.8 \mathrm{~N}$ (by $389 \%$ ), which is very high. This high fluctuation of vibration amplitude may be explained by the appearance of chatter or resonant vibration. Amplitude of chatter changed more sharply in the speed range from 75 to 175 and from 225 to 275 $\mathrm{m} / \mathrm{min}$ and then started decreasing. As it may be observed from Fig 4 and Fig. 7, the average surface roughness values in the case of this material was much higher than that of stainless steel at the initial cutting speed values but the pattern of the curve is a bit different from that of stainless steel. The roughness values continuously fell with cutting in a wide rage of cutting speed. Roughness values in the cutting speed range 175 to $300 \mathrm{~m} / \mathrm{min}$ are quite comparable to those of stainless steel in the range 50 to $140 \mathrm{~m} / \mathrm{min}$. The average surface roughness of the work piece varied from $0.71 \mu \mathrm{m}$ to $0.10 \mu \mathrm{m}$ for these cutting conditions. The continuous fall in the surface roughness values with cutting speed, may be related to the serration of chips in the case of mild steel, as may be observed from Fig. 8, although some marks of vibration may be noticed in the chip section. Due to intensive tool wear and frequent tool breakages the cutting speed was limited to $300 \mathrm{~m} / \mathrm{min}$. The values of amplitude and surface roughness for two tool holder diameters and other cutting conditions are listed in the Tables 3 and 4.

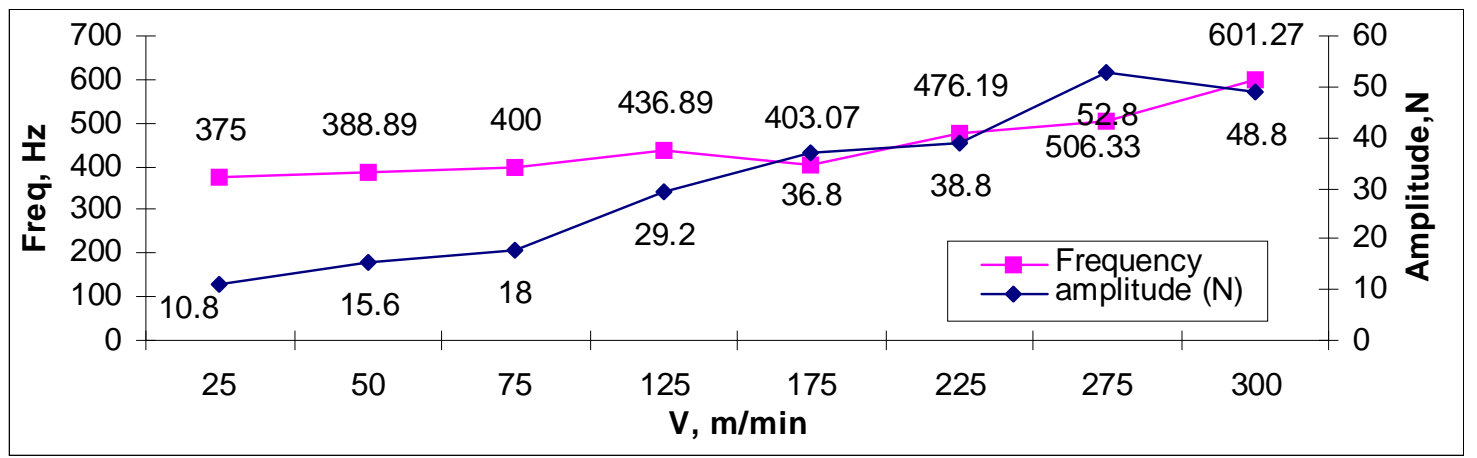

Fig. 6: Variation of frequency and amplitude of chatter with cutting speed. Work Material: Mild Steel, Feed: 0.10 $\mathrm{mm} /$ tooth, Depth: $2 \mathrm{~mm}$ 


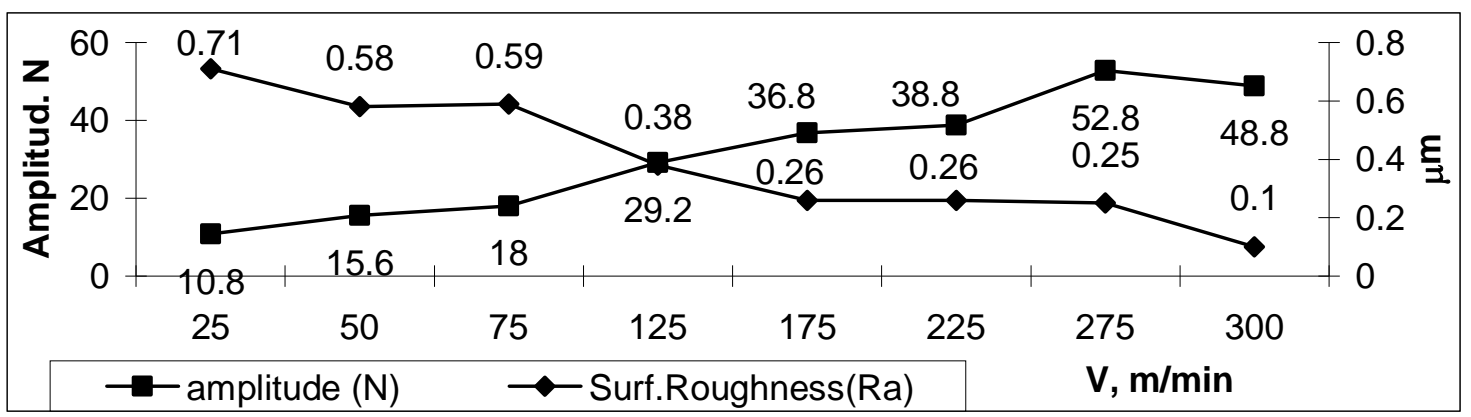

Fig. 7: Dependence of surface roughness on amplitude of chatter and cutting speed. Work Material: Mild Steel, Feed: $0.10 \mathrm{~mm} /$ tooth, Depth: $2 \mathrm{~mm}$

Table 3a: Recommended Cutting Condition to satisfy surface roughness Quality Criteria and Force Amplitude of Vibration

\begin{tabular}{|c|c|c|c|c|c|c|}
\hline \multirow{3}{*}{ Material } & & \multicolumn{5}{|c|}{ End Mill Cutter $\varnothing 20$} \\
\hline & \multirow{2}{*}{$\begin{array}{c}\text { Feed } \\
\text { Depth Of } \\
\text { Cut }\end{array}$} & 0.05 & \multicolumn{2}{|c|}{0.1} & \multicolumn{2}{|c|}{0.2} \\
\hline & & \multicolumn{2}{|c|}{1.5} & 2 & 1.5 & 2 \\
\hline \multirow{28}{*}{ 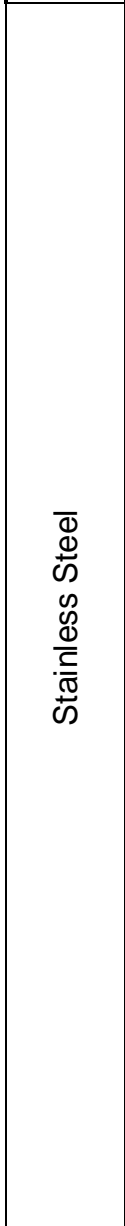 } & Speed & 0.96 & 1.91 & & & \\
\hline & 10 & 24.64 & 6.4 & & & \\
\hline & \multirow[t]{2}{*}{15} & & 1.66 & & & \\
\hline & & & 27.2 & & & \\
\hline & \multirow[t]{2}{*}{20} & 0.76 & & & & \\
\hline & & 36.8 & & & & \\
\hline & \multirow[t]{2}{*}{25} & \multirow{2}{*}{\multicolumn{2}{|c|}{\begin{tabular}{|c|}
1.02 \\
17.28 \\
\end{tabular}}} & & & \\
\hline & & & & & & \\
\hline & \multirow[t]{2}{*}{30} & 0.64 & & & & \\
\hline & & 21.92 & & & & \\
\hline & \multirow[t]{2}{*}{35} & & 0.5 & & & \\
\hline & & & 38.24 & & & \\
\hline & \multirow[t]{2}{*}{40} & 0.43 & & & & \\
\hline & & 12.32 & & & & \\
\hline & \multirow[t]{2}{*}{45} & & 0.76 & & & \\
\hline & & & 38.24 & & & \\
\hline & \multirow[t]{2}{*}{50} & 1.12 & & & & \\
\hline & & 23.36 & & & & \\
\hline & \multirow[t]{2}{*}{55} & & 0.69 & & & \\
\hline & & & 36.48 & & & \\
\hline & \multirow[t]{2}{*}{60} & 0.98 & & & & \\
\hline & & 28.48 & & & & \\
\hline & \multirow[t]{2}{*}{65} & & 0.60 & & & \\
\hline & & & 28.64 & & & \\
\hline & \multirow[t]{2}{*}{70} & 0.73 & & & & \\
\hline & & 31.84 & & & & \\
\hline & \multirow[t]{2}{*}{75} & & 0.64 & & & \\
\hline & & & 37.28 & & & \\
\hline
\end{tabular}

Table 3b: Recommended Cutting Condition to satisfy surface roughness Quality Criteria and Force Amplitude of Vibration

\begin{tabular}{|c|c|c|c|c|c|c|}
\hline \multirow{3}{*}{ Material } & \multirow{3}{*}{$\begin{array}{c}\text { Feed } \\
\text { Depth Of } \\
\text { Cut }\end{array}$} & \multicolumn{5}{|c|}{ End Mill Cutter $\varnothing 20$} \\
\hline & & 0.05 & \multicolumn{2}{|c|}{0.1} & \multicolumn{2}{|c|}{0.2} \\
\hline & & \multicolumn{2}{|c|}{1.5} & 2 & 1.5 & 2 \\
\hline \multirow{20}{*}{$\begin{array}{l}\bar{\Phi} \\
\Phi \\
\stackrel{ \pm}{0} \\
\overline{0} \\
\dot{\bar{\Sigma}}\end{array}$} & \multirow[t]{2}{*}{$\begin{array}{c}\text { Speed } \\
50\end{array}$} & & 1.37 & 1.02 & 0.32 & 0.34 \\
\hline & & & 9.2 & 12.4 & 16.96 & 17.44 \\
\hline & \multirow[t]{2}{*}{75} & & 0.92 & 0.89 & 0.34 & 0.3 \\
\hline & & & 13.6 & 14.2 & 53.6 & 37.08 \\
\hline & \multirow[t]{2}{*}{100} & & 1.07 & 0.93 & 0.3 & 0.32 \\
\hline & & & 16.4 & 26.8 & 35.2 & 17.6 \\
\hline & \multirow[t]{2}{*}{125} & & 0.91 & 0.86 & 0.29 & 0.32 \\
\hline & & & 14.8 & 16.4 & 34.8 & 38.24 \\
\hline & \multirow[t]{2}{*}{150} & & 1.07 & 0.95 & 0.3 & 0.31 \\
\hline & & & 24.8 & 32 & 30.8 & 25.44 \\
\hline & \multirow[t]{2}{*}{175} & & 0.83 & 0.81 & 0.29 & 0.29 \\
\hline & & & 19.2 & 20 & 65.2 & 38.24 \\
\hline & \multirow[t]{2}{*}{200} & & 0.9 & 0.82 & 0.28 & 0.29 \\
\hline & & & 28.4 & 36.8 & 32.4 & 31.36 \\
\hline & \multirow[t]{2}{*}{225} & & 0.76 & 0.67 & 0.29 & 0.3 \\
\hline & & & 22.4 & 26.8 & 62.8 & 38.24 \\
\hline & \multirow[t]{2}{*}{250} & & 0.72 & 0.63 & & 0.3 \\
\hline & & & 33.2 & 42.8 & & 28.32 \\
\hline & \multirow[t]{2}{*}{275} & & 0.32 & 0.27 & & 0.29 \\
\hline & & & 30 & 35.6 & & 38.24 \\
\hline
\end{tabular}


Table 3c: Recommended Cutting Condition to satisfy surface roughness Quality Criteria and Force Amplitude of Vibration

\begin{tabular}{|c|c|c|c|c|c|c|}
\hline \multirow{3}{*}{ Material } & \multirow{3}{*}{\begin{tabular}{|c|} 
Feed \\
Depth Of Cut
\end{tabular}} & \multicolumn{5}{|c|}{ End Mill Cutter $\varnothing 20$} \\
\hline & & 0.05 & \multicolumn{2}{|c|}{0.1} & \multicolumn{2}{|c|}{0.2} \\
\hline & & \multicolumn{2}{|c|}{1.5} & 2 & 1.5 & 2 \\
\hline \multirow{28}{*}{ 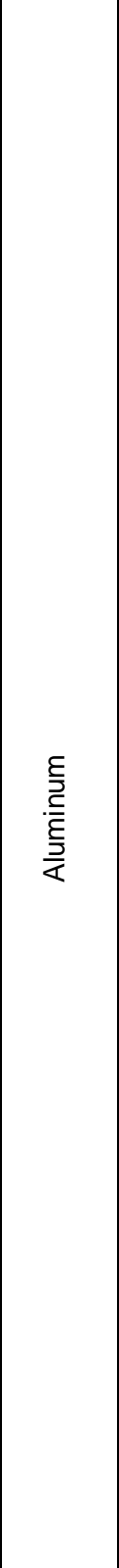 } & Speed & & 0.91 & 0.42 & 0.79 & 0.8 \\
\hline & 50 & & 12.96 & 12.48 & 11.2 & 12.96 \\
\hline & & & & 0.57 & 0.61 & 0.58 \\
\hline & \multirow[t]{2}{*}{75} & & & 14.24 & 26 & 25.28 \\
\hline & & & 0.64 & 0.45 & 0.32 & 0.45 \\
\hline & \multirow[t]{2}{*}{100} & & 18.08 & 19.36 & 29.2 & 36.4 \\
\hline & & & & 0.56 & 0.19 & 0.43 \\
\hline & \multirow[t]{2}{*}{125} & & & 20.64 & 52.8 & 32 \\
\hline & & & 0.55 & 0.43 & 0.2 & 0.42 \\
\hline & \multirow[t]{2}{*}{150} & & 22.08 & 22.08 & 72.8 & 36 \\
\hline & & & & 0.45 & & \\
\hline & \multirow[t]{2}{*}{175} & & & 18.24 & & \\
\hline & & & 0.54 & 0.48 & & \\
\hline & \multirow[t]{2}{*}{200} & & 18.4 & 35.04 & & \\
\hline & & & & 0.53 & & \\
\hline & \multirow[t]{2}{*}{225} & & & 25.6 & & \\
\hline & & & 0.5 & 0.58 & & \\
\hline & \multirow[t]{2}{*}{250} & & 21.28 & 34.72 & & \\
\hline & & & & 0.7 & & \\
\hline & \multirow[t]{2}{*}{275} & & & 26.16 & & \\
\hline & & & 0.54 & & 0.31 & 0.28 \\
\hline & \multirow[t]{2}{*}{300} & & 36.32 & & 70.4 & 38 \\
\hline & & & 0.48 & & 0.56 & 0.48 \\
\hline & \multirow[t]{2}{*}{350} & & 33.76 & & 82.4 & 40 \\
\hline & & & 0.48 & & 0.37 & 0.32 \\
\hline & \multirow[t]{2}{*}{400} & & 36.64 & & 94 & 74.8 \\
\hline & & & 0.51 & & 0.22 & 0.32 \\
\hline & 450 & & 33.28 & & 75.6 & 92 \\
\hline
\end{tabular}

Bold Faced Figures: Acceptable Values that meeting grinding surface criteria $0.1-1.60 \mu \mathrm{m}$

Force Amplitude limited up to $40 \mathrm{~N}$

Upper values in each cell represent surface roughness $\mathrm{Ra}$ $(\mu \mathrm{m})$

Lower values in each cell represent Force Amplitude (N)
Table 4a: Recommended Cutting Condition to satisfy surface roughness Quality Criteria and Force Amplitude of Vibration

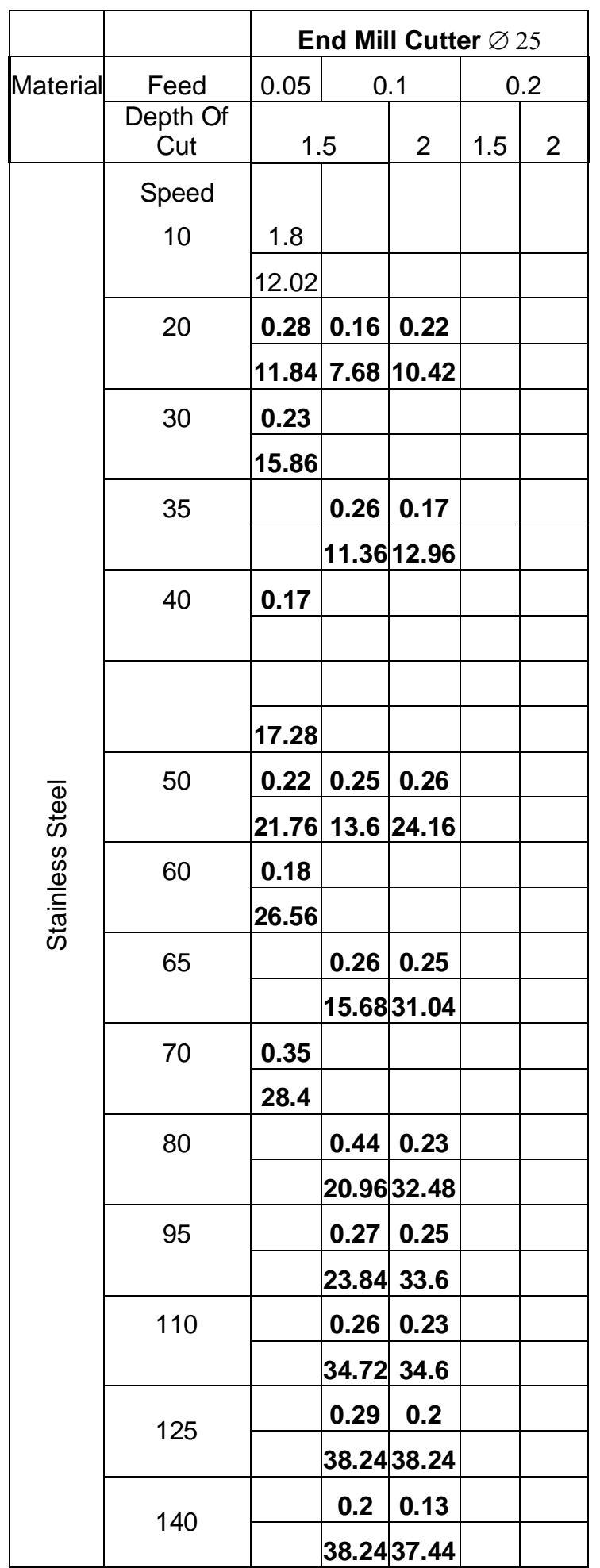


Table 4b: Recommended Cutting Condition to satisfy surface roughness Quality Criteria and Force Amplitude of Vibration

\begin{tabular}{|c|c|c|c|c|c|c|}
\hline \multirow{3}{*}{ Material } & \multirow[b]{2}{*}{ Feed } & \multicolumn{5}{|c|}{ End Mill Cutter $\varnothing 25$} \\
\hline & & \multirow{2}{*}{$\begin{array}{r}0.05 \\
1.5 \\
\end{array}$} & \multicolumn{2}{|c|}{0.1} & \multicolumn{2}{|c|}{0.2} \\
\hline & Depth of Cut & & & 2 & 1.5 & 2 \\
\hline \multirow{24}{*}{$\begin{array}{l}\bar{\Phi} \\
\Phi \\
\bar{\omega} \\
\overline{0} \\
\overline{\bar{Z}}\end{array}$} & \multirow[t]{2}{*}{$\begin{array}{c}\text { Speed } \\
25\end{array}$} & & 1.17 & 0.71 & & 0.83 \\
\hline & & & 8.8 & 10.8 & & 14.8 \\
\hline & \multirow[t]{2}{*}{50} & & 0.98 & 0.58 & & 0.61 \\
\hline & & & 10.4 & 15.6 & & 13.6 \\
\hline & \multirow[t]{2}{*}{75} & & 0.69 & 0.59 & & \\
\hline & & & 13.2 & 18 & & \\
\hline & \multirow[t]{2}{*}{100} & & & & & 0.4 \\
\hline & & & & & & 28.4 \\
\hline & \multirow[t]{2}{*}{125} & & 0.36 & 0.38 & & \\
\hline & & & 12.4 & 29.2 & & \\
\hline & \multirow[t]{2}{*}{150} & & & & & 0.25 \\
\hline & & & & & & 31.6 \\
\hline & \multirow[t]{2}{*}{175} & & 0.31 & 0.26 & & \\
\hline & & & 27.2 & 36.8 & & \\
\hline & \multirow[t]{2}{*}{200} & & & & & 0.19 \\
\hline & & & & & & 53.2 \\
\hline & \multirow[t]{2}{*}{225} & & 0.16 & 0.26 & & \\
\hline & & & 18.4 & 38.8 & & \\
\hline & \multirow[t]{2}{*}{250} & & & & & 0.18 \\
\hline & & & & & & 37.2 \\
\hline & \multirow[t]{2}{*}{275} & & 0.18 & 0.25 & & 0.16 \\
\hline & & & 34 & 52.8 & & 45.6 \\
\hline & \multirow[t]{2}{*}{300} & & 0.12 & 0.1 & & 0.16 \\
\hline & & & 29.6 & 48.8 & & 52.8 \\
\hline
\end{tabular}

Table 4c: Recommended Cutting Condition to satisfy surface roughness Quality Criteria and Force Amplitude of Vibration

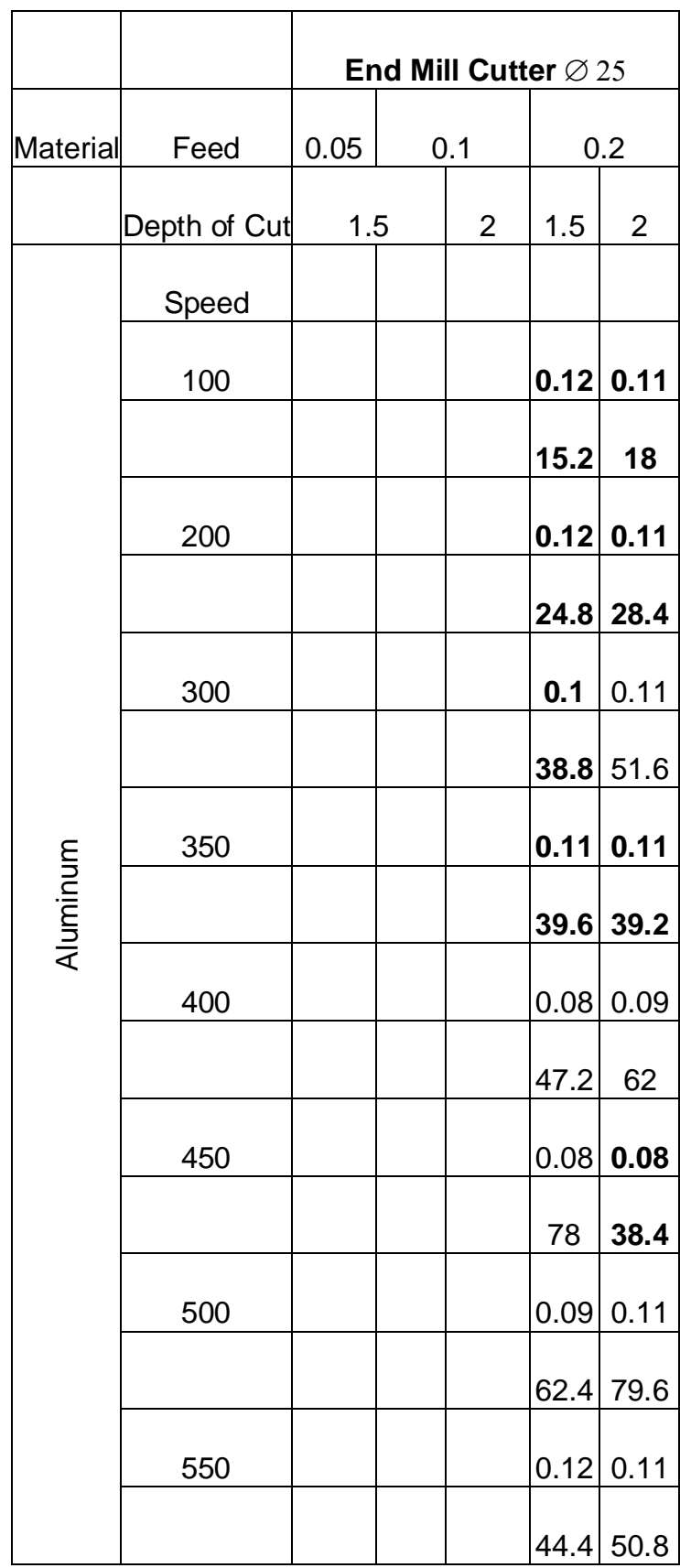

Bold Faced Figures: Acceptable Values that meeting grinding surface criteria $0.1-1.60 \mu \mathrm{m}$

Force Amplitude limited up to $40 \mathrm{~N}$

Upper values in each cell represent surface roughness $\mathrm{Ra}$ $(\mu \mathrm{m})$

Lower values in each cell represent Force Amplitude (N) 


\subsection{Aluminum Alloy}

Curves of chatter/vibration frequencies and amplitude vs. cutting speed and amplitude and average surface roughness vs. cutting speed were plotted for different combinations of feed and depth of cut. Sample relation ships among the above parameters are shown in Fig. 9 and Fig. 10. The feed and depth of cut values used in these cases are $0.20 \mathrm{~mm} /$ tooth and $1.5 \mathrm{~mm}$ respectively. It may be observed from Fig. 9 that the variation in the frequency of vibration is in the range of $221 \mathrm{~Hz}$ to $305 \mathrm{~Hz}$ up to a speed of $500 \mathrm{~m} / \mathrm{min}$, which is not very high (varies only by $38 \%$ ) and may be considered to be practically constant. The amplitude of vibration on the other hand varies from $15.2 \mathrm{~N}$ to $78 \mathrm{~N}$ (by $413 \%$ ), which is very high. This high fluctuation of vibration amplitude again may be explained by the appearance of chatter or resonant vibration. Amplitude of chatter changes more sharply in the speed range

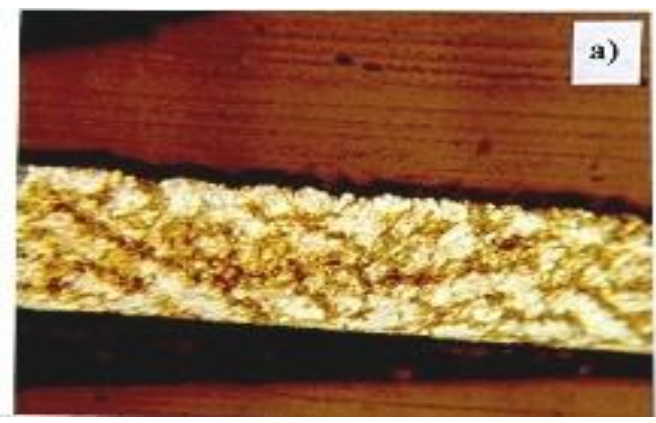

from 100 to 300 and from 400 to $450 \mathrm{~m} / \mathrm{min}$ and then it decreased quite sharply.

Figures 4, 7 and 10 show that the average surface roughness values in the case of this material was much lower than that of stainless steel and mild steel. At the initial cutting speed values $(100-200 \mathrm{~m} / \mathrm{min})$ the roughness values are of the order of $0.12 \mu \mathrm{m}$. Roughness gradually fell up to a speed of 450 (up to $0.08 \mu \mathrm{m}$ ) but then started rising to the initial value of $0.12 \mu \mathrm{m}$. This may me due to the high amplitude of chatter. The chip in this case did not show any sign of serration though marks of vibration were observed in the chip at higher cutting speeds. Due to intensive tool wear and high vibrations, the cutting speed was limited to $550 \mathrm{~m} / \mathrm{min}$. The values of amplitude and surface roughness for two tool holder diameters and other cutting conditions are listed in the Tables 3 and Table 4 along with the other two work materials.

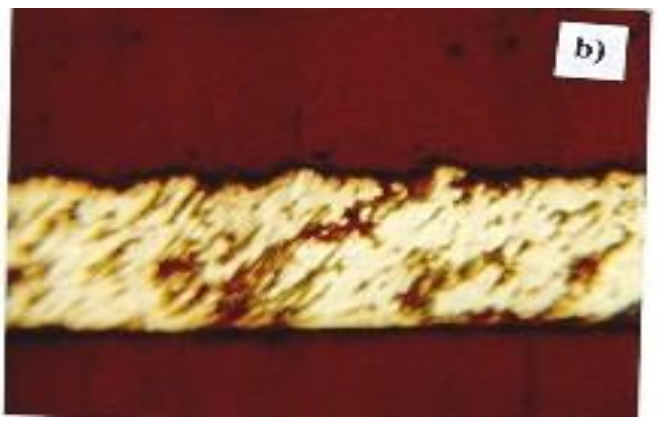

Fig. 8: Photograph of the chip section. Material: Carbon Steel: a) V=50 m/min; b) V=250 m/min.

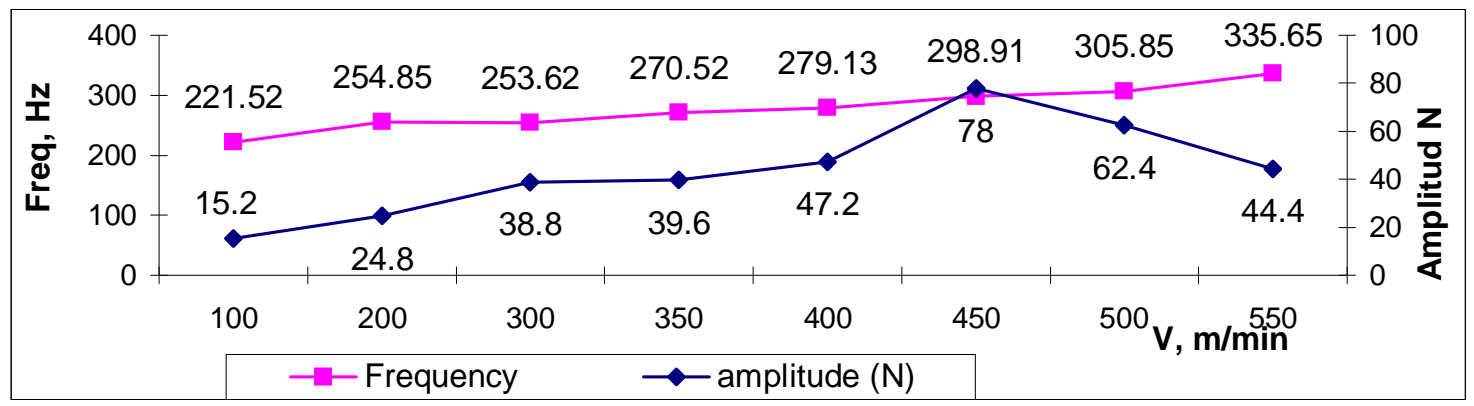

Fig. 9: Variation of frequency and amplitude of chatter with cutting speed. Work Material: Aluminum Alloy, Feed: 0.20 $\mathrm{mm} /$ tooth, Depth: $1.5 \mathrm{~mm}$

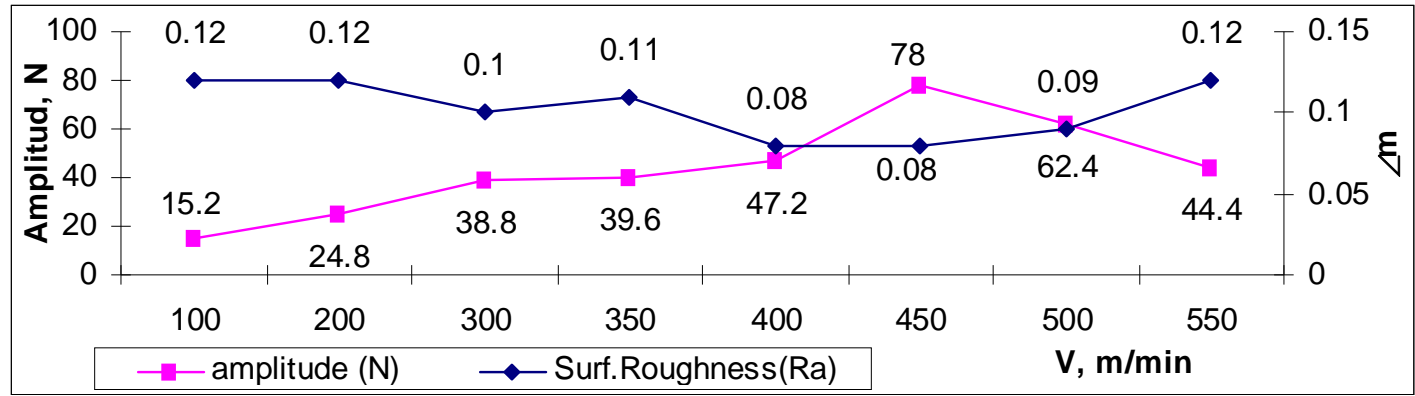

Fig. 10: Dependence of surface roughness on amplitude of chatter and cutting speed. Work Material: Aluminum Alloy, Feed: $0.20 \mathrm{~mm} /$ tooth, Depth: $1.5 \mathrm{~mm}$. 


\subsection{Influence of feed and depth of cut on frequency of vibration}

The vibration frequencies for different conditions were plotted to study their influence on the formation of chatter. It was observed that the frequency of vibration increased with the cutting speed. However, it appears from curves in Fig. 11 that for lower value of depth of cut the higher frequencies. This due to reduction of shear zone where the chip elements can be easily formed or lower energy is required for the formation of the chip elements. The sam

characteristics can be seen in the case of feed variation where lower feed rate will lead to higher

frequency as can be observed in Figure 12. The same relationship holds for the given parameters for different work materials and tool holder diameters.

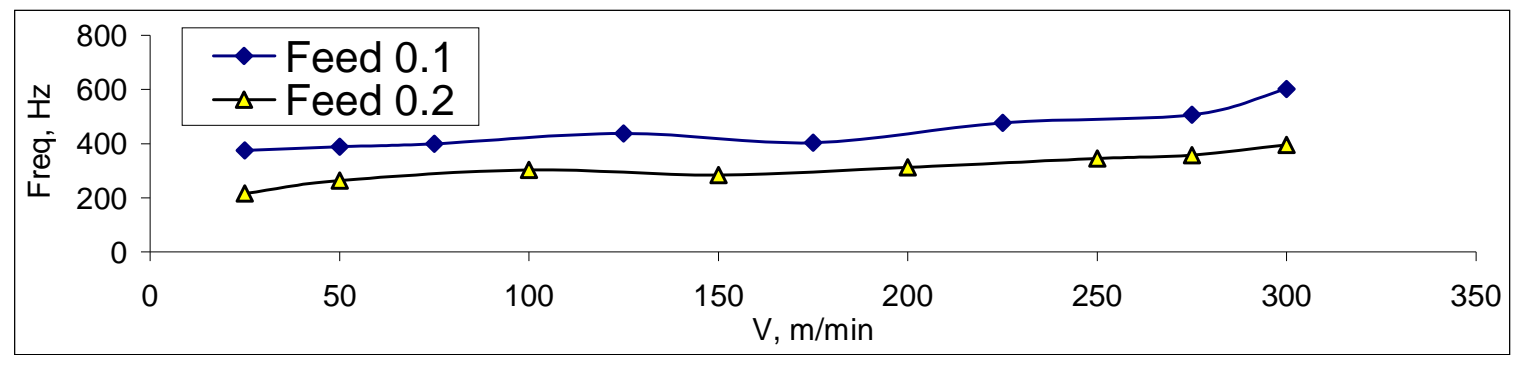

Fig. 11: Influence of cutting speed and depth of cut on frequency of chatter. Material: Mild Steel Feed: $0.2 \mathrm{~mm} / \mathrm{tooth}$, Tool diameter: $20 \mathrm{~mm}$

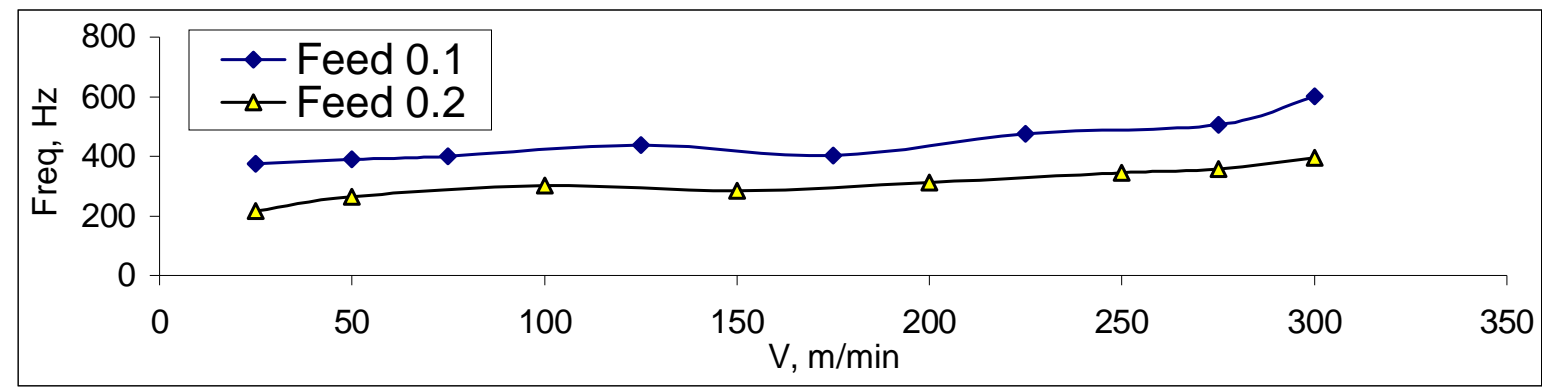

Fig. 12: Influence of cutting speed and feed rate on frequency of chatter. Material: Mild Steel Feed $0.2 \mathrm{~mm} /$ tooth, Tool diameter: $20 \mathrm{~mm}$

\subsection{Influence of tool diameter on Frequency}

The effect of different tool holder diameters on amplitude of chatter and surface roughness may be given in Tables 3 and Table 4. It may be observed from the tables that lower values of tool holder diameter correspond to higher amplitudes of vibration. Lowering of the tool diameter to extremely low values, like 12 $\mathrm{mm}$, leads to drastic reduction of the applicable cutting speed, feed and depth of cut values as supported by the present and previous experimental results.

\subsection{Amplitude and surface roughness values and recommended cutting conditions}

Table 3 and Table 4 lists all the amplitude values expressed in $\mathrm{N}$ and placed at the lower portion of each cell, and the average surface roughness values are listed at the upper portions of the cell. Cutting conditions have been considered acceptable if the amplitude of vibration is below $40 \mathrm{~N}$ and the surface roughness value below $1.6 \mathrm{~mm}$, required for grinding finish (roughness value in the range of $0.4-1.6 \mathrm{~mm}$ is required in grinding and 0.1-0.4 $\mathrm{mm}$ is required in polishing).

\subsection{Analysis of Surface Finish}

The machined surface was observed and analyzed using the SEM in order to explain the causes of gradual improvement of surface finish with the increase of cutting speed. Two samples micrographs are shown in Fig. 13, for mild steel at depth of cut of $2 \mathrm{~mm}$, feed rate $0.1 \mathrm{~mm} /$ tooth at two different cutting speed values. It may be observed from the figure that built-up-edge (BUE) present at relatively lower cutting speeds vanishes at higher speeds. The disappearance of BUE facilitates the reduction of the average surface roughness value at higher cutting speeds. 


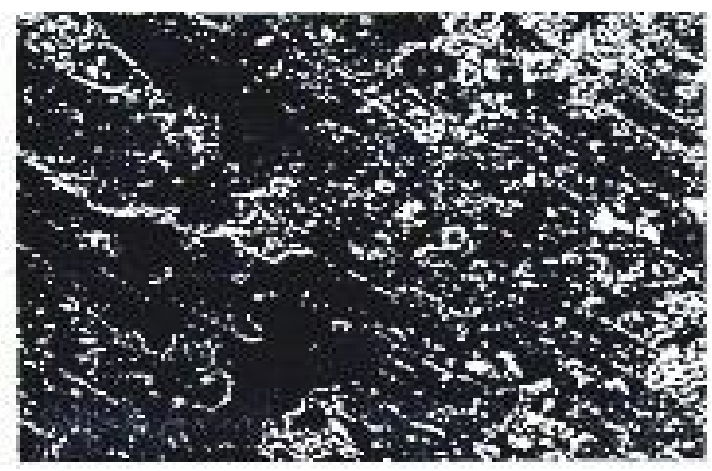

Fig. 13a: Machined surface at speed $=100 \mathrm{~m} / \mathrm{min}$ viewed under SEM

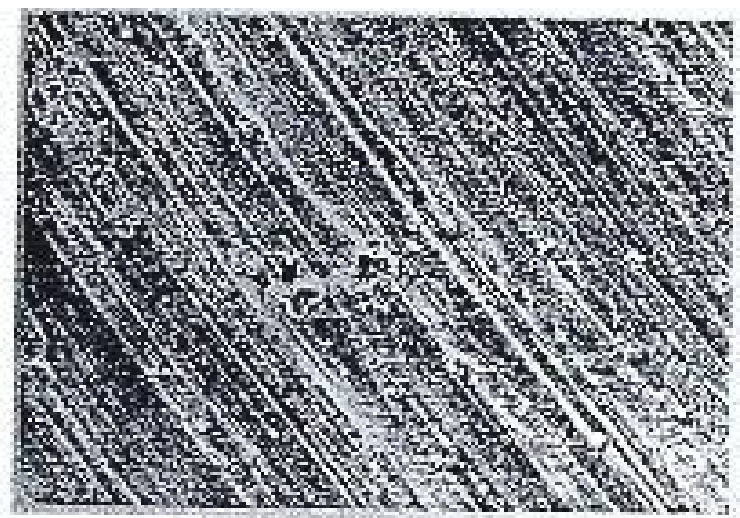

Fig. 13b: Machined surface at speed $=175 \mathrm{~m} / \mathrm{min}$ viewed under SEM

\section{CONCLUSION}

The following conclusions were drawn:

1) Three different types of vibration, associated with the entering of the milling insert in cutting operation during each rotation of the tool, resonant vibration of the tool/fixture elements, and instability/serrated nature of chip formation, were observed.

2) The intermediate frequency vibrations were caused as a result of the interaction of the instability of chip formation process and the natural frequency of the tool/fixture or the work piece. The frequency of this vibration remains practically unchanged over a wide range of cutting speed.

3) Higher frequencies of vibrations were more prominent in the case of stainless steel, which is more prone to serrated chip formation.

4) The surface roughness of machined part is reduced with the increase in cutting speed due to the disappearance of built-up-edge at higher speeds.

5) Increase in the amplitude of chatter leads to higher surface roughness value at higher cutting speed ranges, where machining is accompanied with intensive chatter.

6) Feed and depth of cut have a significant effect on the frequency and amplitude of chatter. Lower feed and depth of cut result in higher frequency of chatter because of the reduction of shear zone, since the chip elements can be easily formed.

\section{ACKNOWLEGEMENT}

This research is funded by the research center, International Islamic University Malaysia.

\section{REFERENCES}

[1] A.K.M.N. Amin and N.V. Talantov,, "Investigation of Chatter on Tool Wear" Mechanical Engineering Res. Bulletin, 10, pp. 11-18, 1987.

[2] A.K.M.N. Amin and M.K. Khalil, Investigation Of Chatter Arising in Machine-Tool-Fixtures-Work (MTFW) System during Turning", Proceeding of International Conference on Advanced Manufacturing Technology, Johor Baru, Malaysia, 29 - 30 August, 1994.

[3] A.K.M.N. Amin, Investigation of The Mechanism Of Chatter Formation During Metal Cutting Process", Mechanical Engineering Res. Bulletin, 6, pp. 12-18, 1983.

[4] M.A. Rizal and M. Razman, Investigation of Chatter Arising During Metal Cutting on Vertical Machining Center, Final Year Project Report, Faculty of Engineering, IIUM, Kuala Lumpur, 2000.

[5] K. Jemialniak,, and A. Windota,, "Supression of Selfexcited Vibration by Spindle Speed Variation Method", Int. J. Mach. Tool Des. Res. 24, pp. 207-214, 1984.

[6] E. M. Trent, Metal Cutting, Butterworth-Heinemann Ltd, 5th edition, 2000.

\section{BIOGRAPHY OF THE AUTHORS}

Dr. A.K.M. Nurul Amin is currently working as an Associate Professor and Head of the Department of Mechanical Engineering, Faculty of Engineering, International Islamic University Malaysia. He was previously serving as Head of department of Industrial and Production Engineering, Bangladesh University of Engineering and Technology. $\mathrm{He}$ was born in Bangladesh in 1954. He obtained his M.Sc. degree in Production Engineering from Volgograd Polytechnic Institute in 1979 and Ph.D. from Georgian Polytechnic Institute in 1982. His areas of interest are machinability, machine tool chatter and optimization of metal cutting processes.

Mohd Rizal Alkahari and Razman Mustafa are born in Malaysia. They graduated from Department of Mechanical Engineering. Faculty of Engineering, International Islamic University Malaysia in the year 2000. They are currently employed as practicing engineers in manufacturing sector of Malaysia. 